\title{
The consumer in the midst of two distinct terms for the quality of goods in Ghana: Can the law be simplified?
}

\author{
Nuhu Yidana* \\ Languages and Liberal Studies Department, Tamale Technical University, \\ P.O box 3E/R, Tamale, Ghana; School of Law \& Politics, University of Hull, HU6 7RX, Hull, UK \\ * E-mail of the corresponding author: chiefyidana@gmail.com/ n.yidana@hull.ac.uk
}

\begin{abstract}
This paper examines the suitability of the concurrent operation of the term of 'free from defects' and the term of 'merchantability quality' as the basic standard terms for the quality of goods respectively in sale of goods contracts and hire-purchase transactions involving consumers in Ghana. The analysis is explored in comparison with the law in England and Wales. The paper argues that the distinct operation of the two different terminologies defining the requirements for the quality of goods respectively in sale of goods contracts and hire-purchase transactions in Ghana has the susceptibility of predisposing consumers to uncertainties regarding which standard term to expect in a transaction. In considering resolving the likely uncertainties of the different terminologies with a uniform standard term similar as pertains under the law in England and Wales, the paper contends that the term to be adopted should be one which is educative and effectively preserves the aspirations of consumers in Ghana. The paper therefore proffered recommendations discerning from the comparative analysis for legislative consideration in Ghana.
\end{abstract}

Keywords: consumer protection, free from defects, merchantable quality, satisfactory quality and comparative law

DOI: $10.7176 / \mathrm{JLPG} / 94-19$

Publication date: February $29^{\text {th }} 2020$

\section{Introduction}

The Sale of Goods Act 1962 Act 137 (herein referred to as SGA) and the Hire-purchase Decree 1974 NRCD 292 (herein referred to as HPA) respectively regulates contractual relationships involving the sale of goods and hirepurchase transactions in Ghana. At the heart of these statutes is the stipulated standard requirements for the quality of goods. The statutes distinctively clarified that the standard requirements for the quality of goods applies in transactions which occurs in the ordinary course of the seller's business, and not when the seller sold the goods in his private capacity (section 13 (1)(a)(iii) of the SGA 1962 and section 14 \& 24(3) of HPA 1974). ${ }^{1}$ However, the statutes did not differentiate between buyers of goods for commercial purpose and buyers of goods for private use. This, therefore, appears to point to the fact that the standard requirements for the quality of goods applies equally to both commercial buyers and consumer buyers of goods.

The application of the statutes standard requirements for the quality of goods to consumer transactions are especially important as there is presently no legislation that is specifically dedicated to the protection of the rights of consumers in Ghana (Dowuona-Hammond 2018; Dowuona-hammond \& Atuguba 2006, p26; Yidana 2019, p16). The coverage of consumer transactions under the statutes is further significant in that the incontrovertible goal of every consumer is to buy goods which are of the required standard of quality generally associated with the particular class of goods. In effect, a consumer who is supplied with goods which turns-out to be faulty or 'lemon' goods, ${ }^{2}$ may be able to seek a remedy for the breach of the seller's obligation to supply goods of the required quality as stipulated under the statutes (Andreas Bschor GMBH \& Co. KG v Birim Wood Complex Ltd \& Birim

\footnotetext{
${ }^{1}$ Instances where the courts have had the opportunity of commenting on sale in the ordinary course of a business can be seen in Andreas Bschor GMBH \& Co. KG v Birim Wood Complex Ltd \& Birim Timbers Ltd (2016) GHSC, NO.J4/9/2015; New Lucky Electrical Ltd. v Startrack Int. Ghana Ltd and another [2010] Suit No. OCC 49/08.

${ }^{2}$ The term 'lemon' goods was explained by Akerlof to be the consequence of asymmetric information which serves as incentives for the representation of low quality goods as high-quality by sellers, thereby lowering the overall quality of goods in the market. For details, see, George A Akerlof, 'The market for "lemons": Quality uncertainty and the market mechanism, In Uncertainty in economics' (1978), Academic Press, 235-251
} 
Timbers Ltd (2016) GHSC, NO.J4/9/2015, pp[4-5]) ${ }^{1}$

The problem, however, is that the standard term adopted as representing the requirements for the quality of goods under the SGA is different from the quality standard term provided under the HPA. Specifically, the stipulated standard term for the quality requirements of goods under the SGA is that the goods are to be 'free from defects' unless disclosed before or at the time of the contract formation (section 13 (1)(a) of the SGA 1962). On the other hand, the laid down standard term for the quality requirements of goods under the HPA is that the goods are to be of 'merchantable quality (section 14 (1) of the HPA 1974). Whilst the statutes use of different standard terms for the quality requirements of goods may not pose serious problems to commercial buyers and to lawyers, this may nevertheless present daunting challenges to the average consumer in identifying the applicable term in every given transaction.

This paper therefore seeks to argue that consumers may be better protected if a uniform standard expression is applied to all transactions relating to the sale of goods and hire-purchase contracts in Ghana. The analysis will be conducted in comparison with the express standard term for the quality requirements of goods under the law in England and Wales. The paper will especially endeavour to ascertain the standard term for the quality of goods that will likely be suitable in better responding to the course of consumers in both sale of goods and hire-purchase transactions in Ghana. In search for a likely suitable standard term for both sale of goods and hire-purchase contracts, the paper will advocate for priority to be given to a more consumer-focused standard term for the quality of goods in Ghana. In the light of this, the analysis will set the stage by commencing with highlights of the philosophical groundings that underscored a more consumer tailored regime generally for the protection of consumers. This would be follow-up with the main analysis of the standard term(s) for the quality requirements of goods under the law in Ghana. The identified concerns of the prevailing standard requirements for the quality of goods in Ghana will then be explored through the lens of the law in England and Wales whilst taking into account the domestic circumstances in Ghana. ${ }^{2}$ Set out below is the rationale for a more consumer-focused standard term for the quality of goods in Ghana.

\section{Rationale for a consumer-focused term for the quality of goods in Ghana}

One of the key tools which undoubtedly enhances the protection of the rights of consumers is access to information about the quality of the goods they buy (Howells 2005). However, information asymmetry about the quality of the goods mostly remains the inevitable challenge of consumers when buying goods (Ramsay 2012, p41; Howells 2005; Twigg-Flesner \& Schulze 2010, p130; Twigg-Flesner 2004; Department for Business, Innovation and Skills, 2014, p10 \& 2013, paras $5 \& 40$ ). The de facto insufficient knowledge of the quality of the goods consequently leaves consumers with the option of taking 'a gamble as to whether the goods will be of the quality they can reasonably expect' whenever they buy goods (Twigg-Flesner 2004). The disturbing issue of consumers taking a gamble to buy goods without adequate knowledge of the quality levels of the goods is the weak bargaining power they have to often demand a certain degree of protection against faulty goods (Ramsay 2012, p41; Howells 2005; Twigg-Flesner \& Schulze 2010, p130; Twigg-Flesner 2004). Benjamin's Sale of Goods has aptly summarised the plight of the consumer by stating that: '[t]he buyer by virtue of haste, ignorance, gullibility, inferior bargaining position or simple imprudence enter into transaction in which the goods supplied or the terms of the contract, or both, are unsatisfactory to him: and in many circumstances, it may be felt that he is deserving of protection whatever he may appear to have agreed' (Bridge 2017, para.14.001).

Indeed, the court in Ghana took judicial notice of the rationale for legislative intervention in consumer transactions in Yayo $v$ Nyinase [1975] 1GLR 422, CA. It was particularly stated that the whole history of the legislature incursion into consumer contracts is primarily for 'the protection of the buyer, hirer or consumer from the cupidity and rapacity of the sellers or owners and from their own inexperience and gullibility.' It was further stressed by the court that: 'the trend of the legislature has been to limit the rights of the owner or seller at common law and to confirm more effective rights on the buyer, hirer or consumer'(Yayo v Nyinase [1975] 1GLR 422, CA). While welcoming the legislative activism for the protection of consumers, commentators have not missed the opportunity to advocate that the protection must not be complex to understand (Bridge 2017, para. 14.001; BIS, 2014, p10; Ramsay 2012, p41; Twigg-Flesner and Schulze 2010; Ansa-Asare 1981).

So, clearly, there is a neatly demonstrable support based for legislative intervention in ensuring that the interest of

\footnotetext{
${ }^{1}$ While noting that a breach may either be a condition or a warranty as prescribed by the statute (the SGA 1962), the court stated at page 5 that a breach of a condition entitles the buyer to reject the goods, but a breach of warranty entitles the buyer to only damages.

${ }^{2}$ For the sake of simplicity, the term 'English law' will be use in place of 'England and Wales law' throughout the discussion.
} 
the consumer is not undermined. Moreover, the legislative incursion into the trajectory of consumer protection need to be fashion out in a consumer tailored manner to which consumers may easily appreciate. This is important to ensure that the gullible and inexperience consumer with inadequate knowledge about the quality of the goods is not confined to only the mercy of the well-informed and powerful seller. To this end, the current standard term(s) for the quality of goods in Ghana is examined below while taking into consideration the degree to which the term(s) may be appreciated with ease by consumers.

\section{The standard term(s) for the quality of goods under the law in Ghana}

This section examines the express standard term(s) for the quality of goods for the purposes of consumer protection in Ghana. As mentioned earlier, the standard term(s) for the quality of goods are visibly provided under the SGA and the HPA. The terms in both regimes are considered serially below in appreciating what the law has provided for the benefit of consumers. The analysis endeavour to highlight the substantive issues that need resolving to appropriately position the regime for the protection of consumers in Ghana. The main analysis of the law is set out below.

\subsection{The issue of different standard terms for the expression of quality of goods in Ghana}

Under the law in Ghana, two principal statutes defined the obligations of sellers regarding the sale and supply of goods to consumers (SGA 1962 \& HPA 1974). One of the key obligations of traders under the statutes is the implied duty to supply quality goods to consumers in a contract of sale of goods, and of hire-purchase (section 13 (1) (a), SGA 1962; section 14, HPA 1974). Both the SGA and the HPA adopted a standard term for the quality of goods which must be satisfied in respect of the goods a seller is supplying to a consumer under the law in Ghana. It is interesting to note that the statutes opted for different standard terminologies in imposing the obligation on traders to supply quality goods to consumers as noted earlier. In the first instance, the Sale of Goods Act 1962 stipulates that: '.. there is no implied warranty or condition as to the quality ... of goods supplied under a contract of sale except (a) that there is an implied condition that the goods are free from defects which are not declared or known to the buyer before or at the time when the contract is made'. Our focused here is concerned with the requirement for a seller to supply goods under a contract of sale which are 'free from defects' as a standard requirement for the quality of goods in Ghana.

It is important to note that the obligation of traders to supply goods which are free from defects unless declared applies equally to both new and second hand-goods. This has been affirmed consistently by the Supreme Court that: “... a seller of either first or second-hand goods is ...liable for all defects in them.'(Continental Plastics Engineering Co. Ltd. v IMC Industries - Technik GMBH [2009] SCGLR 298, p304; Georgia Hotel Ltd v Silver Star [2012] 2 SCGLR; G. A. Sarpong \& Co. v Silver Star Auto Ltd [2010] OCC10/2009; also, Mills 1978). The statutory stipulation for sellers to supply goods which are free from defects has been held by the courts to be an implied condition of sale of goods contracts (Georgia Hotel Ltd v Silver Star [2012] 2 SCGLR; G. A. Sarpong \& Co. v Silver Star Auto Ltd [2010] OCC10/2009; Continental Plastics Engineering Co. Ltd. v IMC Industries Technik GMBH [2009] SCGLR 298). The application of the provision essentially '...hinges on whether or not at the time of the sales contract, there were defects, latent or otherwise in the goods complained of.'(G. A. Sarpong \& Co. v Silver Star Auto Ltd [2010] OCC10/2009, p4). It has, therefore, been stressed that: ' ...if there were defects, ... the seller cannot escape liability for the breach of an essential condition of the contract" (Continental Plastics Engineering Co. Ltd. v IMC Industries - Technik GMBH [2009] SCGLR 298, p304).

In sum, the standard term for the quality requirements of goods which a trader is expected to supply to consumers in a contract of sale of goods is that the goods should be free from defects which are not disclosed. In effect, a consumer who bought goods which are discovered to be faulty or defective will be entitled to rely on the implied obligation of the trader to seek for a remedy.

However, the requirement that the goods should be free from defects which are not disclosed will not apply to a consumer who buys goods and the mode of payment is by instalments or fulfilment of other conditions of the contract. In such instance, the consumer may be able to come under the requirement that the goods should be of merchantable quality. This is provided under the Hire-purchase Decree 1974, NRCD 292. Section 14 (1) of the statute states that: 'in every hire-purchase or conditional sale agreement there shall be implied a term that the goods will be of merchantable quality at the time of delivery'(HPA 1974). The doctrine of merchantable quality as the standard term for the quality of goods in relation to hire-purchase agreement has not received sufficient judicial determination by the courts in Ghana. In one instance in which the court had the occasion to comment on the term was in the case of Rockson v. Armah ([1975] 2 GLR 116, p120) which itself was concerned with the SGA under 
which the hire-purchase provisions were initially based. ${ }^{1}$ It was stated by the court that the second-hand car which was the subject of the dispute in the instant case, would be merchantable if in a usable condition, even when not perfect.(Rockson v Armah [1975] 2 GLR 116, p120; see also, Nkansah 2015). The point worth emphasising is that a consumer who acquired his goods under a hire-purchase or a conditional sale transaction will only be able to seek a remedy by relying on the breach of the standard term of merchantable quality.

So, clearly, the standard requirement for the quality of goods in contracts for the sale of goods differs from the standard term of quality of goods in respect of hire purchase or conditional sale agreements. The question to ask, however, is whether the variation of the quality standard expression is suitable in safeguarding the interest of consumers in Ghana as regards a consumer who is supplied with faulty goods. Essentially, whilst the different terms for the quality of goods may not pose a challenge to a trained lawyer in being able to identify the applicable law with precision, this may not be the case for the average consumer in Ghana without legal background. Similarly, a commercial buyer may have less difficulty in appreciating whether the transaction in question relates to the standard set under the SGA or the HPA. However, the operational effect of the two distinct standard terms for the quality of goods will likely pose difficulties to consumers, especially regarding the standard term they should expect in the goods they buy. In other words, the standard term to expect in the goods may create confusion in the minds of average consumers regarding which standard term to expect at any point in time. Aborchie-Nyahe (2014) has asserted that about $95 \%$ of respondents in a survey they conducted revealed that they have had problems with various goods they bought, but never took any action due to their distrust and lack of confidence in the regime.

The functioning of the two standard terms may therefore possibly heighten the worry of consumers particularly as to whether the implied duty of the seller regarding the goods being free from defects or the implied term of merchantable quality is the standard of quality they should rely on for protection when they are supplied with faulty goods. This uncertainty may nevertheless be removed where a broadly effective standard term that has the tendency of reflecting the goals of consumers whether they are buying the goods through contract of sale, hire purchase or conditional sales. Presently as seen however, this does not exist under the regime in Ghana. Addressing this potential source of confusion is important in ensuring that consumers can confidently have a reliable express standard term of quality to which they could clinch on whether they are acquiring their goods under contract of sale or hire purchase.

\section{Can the law in England and Wales offer some guidance in resolving the problem of the different standard terms for the quality of goods in Ghana, but within the local context?}

As observed above, the operation of the distinct terms for the quality of goods under the law in Ghana could create confusion as to what a consumer should exactly expect in goods s/ he purchases. There is therefore the need for the potential complexity to be addressed to help ensure that consumers are afforded a very clear regime in dealing with issues of the quality of goods in Ghana. In comparing with the experience of the UK law, the standard expected of goods which are delivered to consumers is that the goods should be of satisfactory quality. This standard for the quality of goods is provided under section 9 (1) of the Consumer Rights Act 2015 (herein referred to as CRA 2015). It is significant to note that section 9(1) of the CRA is a restatement of section 14 (2) of the SGA 1979. It is further instructive to mention that section 14 (2) of the SGA 1979 had also implemented the EU Consumer Sale Directive (Directive 1999/44/EC) in 2002 (The Sale and Supply of Goods to Consumers Regulations 2002) but opted to retain the term of satisfactory quality instead of conformity as was contained under the Directive (Article 2).

As a restatement of section 14 (2) of the SGA 1979, section 9 (1) of the CRA 2015 states that: '[e]very contract to supply goods is to be treated as including a term that the quality of the goods is satisfactory.' The range of contracts covered for which satisfactory quality is to be treated as a term for the supply of goods to consumers include; sales contracts, contracts for the hire of goods, hire-purchase agreements, and contracts for the transfer of goods (section 3 (2), CRA 2015). It is important to indicate that conditional sales have been recognised as a sales contract under section 5 (3) of the CRA 2015. In Atiyah and Adams' Sale of Goods, it is submitted that: 'wherever a contract between a consumer and a trader involves the supply of goods (whether that is a sale, hire-purchase or hire) the same provisions will apply, although there are minor modifications for certain contracts (Twigg-Flesner, Canavan and MacQueen, 2016, p499). In the CRA 2015 Explanatory Notes, it has similarly been clarified that sales contracts

\footnotetext{
${ }^{1}$ It is worth noting that the court pronouncement on merchantable quality drawing from the SGA under which the agreement was based on the then hire-purchase provision was criticised as a failure to apply the law in dealing with the matter. Nevertheless, the court exposition on merchantable quality is relevant to the present discussion in respect of what the term implies under Ghana law as regards its usage in the hire-purchase statute. For details of the criticism, see, J. E. A. Mills, 'Rockson Armah: A Case of Caveat Emptor, Caveat Venditor or Neither?’ (1978), 15 U. Ghana L.J. 168.
} 
as an element of contracts to supply goods include conditional sales 'where goods are paid for in instalments and the trader retains ownership of the goods until the conditions in the contract have been met, whether the consumer has possession of the goods in the meantime or not'( Explanatory Notes to the CRA 2015, para 58; BIS 2015). In any of these types of contracts to supply goods, the required standard term is that the goods should be of satisfactory quality as mentioned above. The application of uniform rules (including the standard of quality for the present purpose) to various transactions in consumer contracts has been extolled as a welcome development (TwiggFlesner, Canavan and MacQueen, 2016, p499).

The critical issue that triggers the above presentation of the England and Wales law is the guidance that may be drawn to address the confusion that might arise in the face of having two distinct standard terms in respect of sale of goods contracts and hire-purchase transactions in Ghana. This is particularly important to help ensure that any ambiguity the different standards might have is resolved for the benefit of consumers in Ghana. As observed above, the standard term of satisfactory quality under the law in England and Wales applies uniformly to the wide range of transactions involving consumers. The England and Wales law usage of one single term for the quality of goods in respect of the many transactions is very helpful in that when consumers become familiar with the term, they would not confuse it with other competing requirements, as is possibly the case with the different standard terms of quality in Ghana. The important question, however, is which standard term should the regime in Ghana use that would be sufficiently relevant to consumer aspirations and education, and cover both transactions appropriately? Should the regime in Ghana adopt one of the already existing standard terms of quality or the term of satisfactory quality under the law in England and Wales? There is obviously no straightforward answer to any of these questions. There is, therefore, the need for the terms to be appraised in sequence so as to ascertain a term that is likely to be viable in reflecting the education and aspirations of consumers and other key stakeholders.

\subsection{The issue of merchantable quality as a standard term for all transactions in Ghana}

As set out above, the focus here is to address the issue of whether the term of merchantable quality should be adopted as the term for the quality of goods applicable in both sale of goods and hire-purchase transactions in Ghana. Drawing further guidance from the UK law, it is worth noting that prior to the term of satisfactory quality as the standard term for the quality of goods, the standard term for the quality of goods was merchantable quality under the law in England and Wales as provided in respect of the hire-purchase transactions in Ghana. This was, however, replaced with the current satisfactory quality standard term through the 1994 amendment to the 1979 SGA which has now been restated under the CRA 2015 as noted previously. The merchantable quality was broadly found to be more appropriate to transactions involving retailers and wholesalers instead of consumer transactions (The Law Com. 160 and Scot. Law Com. No. 104, 1987, para. 3.10; see also, Willett 1993; Bridge 2003; Bridge 1995; Scott, Black \& Cranston 2000, p159). It was also argued that the term was more attuned to natural products than complicated machinery which is the characteristic of the present-day products in the market (Bridge 1995). Other criticisms were to the effect that the term has fallen out of general use and not suitable to consumer transactions. These criticisms consequently resulted in the Law Commission recommending its displacement (The Law Com. 160 and Scot. Law Com. No. 104, 1987, para. 3.19 - 3.22). Although the Law Commission's recommendation was to the effect of replacing 'merchantable quality' with 'acceptable quality'(The Law Com. 160 and Scot. Law Com. No. 104, 1987, para. 3.19 - 3.22; see also, Twigg-Flesner et' al, 2016, p140). The legislature nevertheless gave preference to 'satisfactory quality' (section 14(2) of SGA 1979 as was amended by the SSGA 1994). The satisfactory quality as was introduced into the SGA 1979 by the SSGA, 1994 amendment is what has been transposed into section 9 of the CRA 2015 as noted earlier. The legislative favour for satisfactory quality had been argued to succeed in avoiding the potential confusion of the then proposed acceptable quality with its element of circularity which had manifested in the pre-1994 amendments of the 1979 SGA (Bridge 1995); Groves 1995).

The criticisms meted out to the 'merchantable quality' concept which led to its replacement under the England and Wales law raises the important question as to whether its adoption as the standard term of quality of goods in both sales contracts and hire-purchases transactions in Ghana would be appropriate to provide consumers with a clear regime? The highlighted criticisms of the merchantable standard term for the quality of goods under the then England and Wales law seem to begin to manifest in the case of Ghana in respect of consumer matters. In her recent article in particular, Dowuona-Hammond (2018) posited that: 'the standard of merchantable quality ... is quite archaic, and not useful, in view of the uncertainties associated with its definition and scope.' In an earlier commentary, the commentator had observed that the Sale of Goods Act 1962, 'Act 137 scrupulously avoids the use of the term "merchantable quality" with its definitional problems and inherent uncertainty of scope and instead refers specifically to "defects" in the goods ...'(Dowuona-Hammond 1995). Moreover, Mills (1978) had also 
argued that with the term of merchantable quality, goods may be bad or of inferior quality but yet fulfil the statutory requirement of being of merchantable quality. He therefore argued that the term was specifically alien to sale of goods transactions and that its application to the sale of goods in determining the quality of goods tends to lower the available protection under the Sale of Goods statute in Ghana.

It is clear from the above submissions that using merchantable quality as the express standard term for the quality of goods in both sale of goods and hire-purchase transactions will not be suitable in consumer transactions in Ghana. It is therefore necessary to further appraised the suitability of the standard term requiring sellers to supply goods which are free from defects to consumers under the current Sale of Goods Act 1962. Before this, however, the term of satisfactory quality under the law in England and Wales is first examined below.

\subsection{The issue of adopting the term of satisfactory quality as a standard term for the quality of goods under sale of goods and hire-purchase transactions in Ghana}

As shown above, adopting the term of merchantable quality to apply uniformly to both sale of goods and hirepurchase transactions will not be suitable in consumer transactions in Ghana. The present subsection therefore considers the question of whether Ghana should adopt the term of merchantable quality as provided under the law in England and Wales.

As noted earlier, section 9 (1) of the CRA 2015 requires satisfactory quality to be treated as a term in every contract for the supply of goods. The CRA 2015 went further to underscore that goods are to be satisfactory quality if a reasonable person would regard the goods as being of satisfactory quality bearing in mind the description of the goods, the price of the goods, and any other circumstance which is relevant in the given instance (section 9(2) of the CRA 2015). The Explanatory Notes to the CRA 2015 states that '... the test of whether or not the quality of the goods is satisfactory is determined by what a reasonable person would consider satisfactory for the goods in question, taking into consideration all relevant circumstances including any description, the price and any public statements by the trader or producer or their representatives, such as statements made in advertisements or on the labels of goods'(The Explanatory Notes to the CRA 2015, para. 62). Beyond the primary definition of satisfactory quality, a further set of non-exhaustive aspects of quality such as fitness for all purposes associated with that kind of goods, freedom from minor defects, appearance and finish, durability and safety are required to be considered if relevant in reaching a decision regarding whether or not the goods in question is of satisfactory quality (section 9(3), CRA 2015). This broad array of elements through which to test the conformity or otherwise of goods to the standard term of satisfactory quality seems to highlight the practical educational utility of the England and Wales regime. In particular, it was observed in the pre-CRA 2015 that while consumers might have difficulty in appreciating the degree of protection predating the inception of the satisfactory quality term, they may be 'more confident that their view of what constitutes "satisfactory quality" is just as valid as that of the seller'(Howells and Weatherill 2005, p170). While referring to the clarification of the relevant circumstances of the satisfactory quality term before the 2015 Act, it was similarly contended that the regime will better enable consumers to effectively bargain with traders (Willett \& Morgan-taylor 2004; Ramsay 2012, p523).

While the above observations properly positioned the doctrine of satisfactory quality capable of being well applied for the benefit of consumers in the UK, it is worth stressing that its educative content is clearly revealed in the broad spectrum of the definition that follows the standard term. The express statement of the standard term itself does not seem to offer sufficient educative function to which consumer needs may be properly served. The editors of Atiyah and Adams' Sale of Goods have particularly observed that the term of satisfactory quality itself like its predecessor is a vague statement and that all vague terms tend to be meaningless or vacuous in practice (TwiggFlesner et' al, p148; see also, Howells and Weatherill 2005, para. 170-1. The editors further contend that such a vague standard term gives 'little guidance as to what kind of defects or damages will render goods unsatisfactory $\ldots$ and are unhelpful in the practical application of the law'(Twigg-Flesner $e t^{\prime}$ 'al, p148).

The term, therefore, turns to be practically relevant by employing the doctrine of reasonableness which renders its application flexible. It has, however, been stressed that: '[t]ests which depend so heavily upon standards of reasonableness tend to be somewhat circular in practice'(Twigg-Flesner et'al, p148; Ervine 2004). It has similarly been contended that the term of satisfactory quality is ' . . a phrase which as elaborated is little more than circular for any dispute"(Ervine 2004). However, the application of the test of reasonableness requires the court to fully evaluate each case with the primary sense of preserving justice (Twigg-Flesner et' al, p149). This, therefore, justifies the courts being empowered to interpret the standard term of satisfactory quality within the context of what a reasonable person would regard as satisfactory quality taking into consideration the description, price and 
other relevant circumstances in each given case. The various elements of satisfactory quality as highlighted above further adds up to make the standard term of satisfactory quality a viable statutory measure with the potential of affording the right fit criterion for the determination of the quality of goods (Yidana 2019).

It is evident from the analysis that the standard term of satisfactory quality has a recognised prominence that could afford very clear guidance to stakeholders in the determination of the satisfactory quality of goods. However, the crucial question is whether the requirement for sellers to supply goods which are free from defects under the SGA 1962 will equally not suffice to be applied to both sale of goods and hire-purchase contracts in Ghana so as to warrant its displacement from the statute books as a standard term for the quality of goods? This invites a further consideration as to whether the requirement that goods should be 'free from defects' is suitable and capable of reflecting the goals of consumers in both sale of goods and hire-purchase contracts in Ghana. This is examined below.

\subsection{The issue of applying 'free from defects' as a standard term for the quality of goods in both sale of goods and hire-purchase transactions in Ghana}

As indicated above, the standard term of satisfactory quality has a recognised prominence that could afford very clear guidance to stakeholders in the determination of the satisfactory quality of goods. It is, however, necessary to ascertain whether the requirement for sellers to supply goods which are free from defects presently under the Sale of Goods Act 1962 in Ghana is not capable of affording consumers with the required protection if extended to cover hire-purchase transactions. For, if the term requiring sellers to supply goods which are free from defects will be viable in affording consumers the needed protection in both sale of goods and hire-purchase transactions when adopted, there would be no need to displacement it in favour of the England and Wales term of satisfactory quality.

The standard requirement is that sellers are under a duty to supply goods which are free from defects unless disclosed as per the SGA 1962 in Ghana. Essentially, the prima facie disposition of the standard term that the goods should be free from defects goes to the point that the goods should be supplied without faults in them unless the faults are declared as previously examined. On account of this, it has been argued that the requirement of the standard term for the quality of goods to be free from defects preserves a very high standard degree of protection for consumers with respect to sale of goods contracts (Dowuona-Hammond 1995; MILLS 1978). This has recently been affirmed by the Supreme Court that the sales law in Ghana 'imposes a heavier responsibility on sellers of goods' to supply the required standard of quality goods to consumers (G. A. Sarpong v Silver Star Auto. Ltd [2014], Suit No. J4/43/2013, p9). The standard term of quality that the goods should be free from defects clearly seems to self-evidently carry some educational value that might generally be useful to consumers. In particular, it has been advised that a statutory standard term of quality must move beyond 'a dispositive purpose' to a 'didactic purpose of educating the consumer or consumer rights organization reading the statute' in order to be a meaningful quality standard term for the effective protection of consumers (Bridge 2003).

From the discourse so far, it seems clear that the existing quality standard term requiring sellers to supply goods which are free from defects remains practically relevant to securing a good degree of protection to consumers in respect of sale of goods contracts in Ghana. In effect, the need does not appear to arise to argue for the displacement of the current standard requirement for the quality of goods in respect of sale of goods contracts in Ghana. It may, therefore, be argued that the standard requirements for the quality of goods that sellers are to supply goods which are free from defects may suitably accommodate not only sale of goods contracts, but also, hire-purchase transactions, if adopted. The adoption of the same quality standard term will ensure that consumers are offered a uniform express standard term of quality they should expect in the goods they buy. This will further address the tendency of the operation of the two distinct terms likely confusion consumers regarding which standard term to expect in a transaction. This is significant to help provide a regime with more certainty to consumers in Ghana. This will be useful in supporting consumers to effectively protect themselves against the chances of seller supplying them with faulty goods in Ghana.

\section{Conclusion}

This article has shown that the current state of the law in which the term for the quality of goods in the sale of goods contracts is different from the term for the quality of goods in hire purchase transactions is not practically helpful to the cause of consumers. In the light of this, this paper clearly postulated that the interest of consumers would be better served with Ghana adopting a uniform standard term for the quality of goods, applicable to both sale of goods and hire-purchase contracts. This is necessary to avoid the likely tendency of the operation of the two different terms confusion consumers as regards the term they should expect in every given transaction. It is 
therefore recommended that a uniform standard term for the quality of goods should be adopted and made applicable to every transaction in which goods are to be supplied to consumers in Ghana. The paper has also demonstrated that the merchantable quality as currently applicable in hire-purchase transactions in Ghana is outdated and not suitable in purely consumer matters. Consequently, the term of merchantable quality is not recommended for adoption as the uniform standard term for the quality of goods in Ghana. While the satisfactory quality term under the law in England and Wales is not inappropriate as demonstrated in the discussion, it is nevertheless clear that the current requirement that the goods should be 'free from defects' unless disclosed remains a relevant statutory measure which sufficiently preserves the educational function and aspirations of consumers in Ghana. This manuscript therefore submits that the requirement that the goods should be 'free from defects' should be adopted as the overall standard term for the quality of goods in all transactions in relation to the sale of goods and hire-purchase in Ghana. This will be significant in eliminating the likely confusion the present different terms of quality of goods may generate in the minds of consumers in Ghana.

\section{References}

\section{Case law:}

Andreas Bschor GMBH \& Co. KG v Birim Wood Complex Ltd \& Birim Timbers Ltd (2016) GHSC, NO.J4/9/2015

Continental Plastics Engineering Co. Ltd. v IMC Industries - Technik GMBH [2009] SCGLR 298

G. A. Sarpong \& Co. v Silver Star Auto Ltd [2010], OCC10/2009

G. A. Sarpong v Silver Star Auto. Ltd [2014], Suit No. J4/43/2013

Georgia Hotel Ltd v Silver Star [2012] 2 SCGLR

New Lucky Electrical Ltd. v Startrack Int. Ghana Ltd and another [2010] Suit No. OCC 49/08.

Rockson v Armah [1975] 2 GLR 116

Yayo v Nyinase [1975] 1GLR 422, CA

\section{Statutes:}

Directive 1999/44/EC of the European Parliament and of the Council of 25 May 1999 on certain aspects of the sale of consumer goods and associated guarantees, EU

The Consumer Rights Act 2015, c 15, UK

The Hire-purchase Decree 1974, NRCD 292, Ghana

The Sale and Supply of Goods Act 1994, UK

The Sale and Supply of Goods to Consumers Regulations 2002, UK

The Sale of Goods Act 1962, Act 137, Ghana

The Sale of Goods Act 1979, UK

\section{Secondary reference:}

Aborchie-Nyahe, I. (2014), "The State of Consumer Protection in Ghana", COMESA, FTC - USA and CFTC, The Sixth Annual African Dialogue Consumer Protection Conference, Lilongwe, Malawi

Akerlof, G. A. (1978), “The market for "lemons": Quality uncertainty and the market mechanism. In Uncertainty in economics" Academic Press, 235-251.

Ansa-Asare, K. (1981). "The case for a comprehensive framework of consumer protection in Ghana" Rev. Ghana L.14(13), 73.

Bridge, M. G. (10th Ed.). (2017), "Benjamin's sale of goods", Sweet \& Maxwell.

_ (1995), “The Sale and Supply of Goods Act 1994”, J. B.L 398

__ (2003) "What Is to Be Done about Sale of Goods?" Law Quarterly Review 119, 173-177

Department for Business Innovation and Skills, (2014) "Consumer Rights Bill: Statement on Policy Reform and Responses to 
Pre-Legislative Scrutiny"

_ (2013) "Draft Consumer Rights Bill: Government Response to Consultations on Consumer Rights"

_ (2014) "Consumer Rights Bill : Statement on Policy Reform and Responses to Pre-Legislative Scrutiny"

2015, "Consumer Rights Act: Goods, Guidance for Business" $<$ https://www.businesscompanion.info/sites/default/files/CRA-Goods-Guidance-for-Business-Sep-2015.pdf $>$ accessed on the $15 / 07 / 2018$

Dowuona-hammond, C. \& Atuguba, R. (2006), "The Policy and Legal Framework for Consumer Protection in Ghana", Friedrich Ebert Foundation (FES)

Dowuona-Hammond, C. (1993). "Protecting the Purchaser of Goods under Ghanaian Law", Rev. Ghana L., 19, 105.

Dowuona-Hammond, C. (2018). "Consumer law and policy in Ghana”, Journal of consumer policy, 41(4), 333-354.

Ervine, WCH. (2004) “Satisfactory Quality: What Does It Mean?”, Journal of Business Law 684

Explanatory Notes to the Consumer Rights Act 2015

Groves, P. (1995). “The Sale and Supply of Goods Act 1994”, Business Law Review, 16(3), 55-57.

Howells, G. (2005) “The Potential and Limits of Consumer Empowerment by Information” Journal of Law and Society 32, 349

Howells, G., \& Weatherill, S. (2005), “Consumer protection law”, 2nd edn, Ashgate.

MILLS, J. E. A., (1978), “Rockson Armah: A Case of Caveat Emptor, Caveat Venditor or Neither?” U. Ghana L.J. 15, 168

Nkansah, L. A. (2015). "Consumer Protection in Ghana: An Appraisal of the Law”, Joseph Ayo Babalola University Law Journal 2(1), 185-200.

Ramsay, I. (2012), “Consumer law and policy: Text and materials on regulating consumer markets”, Hart Publishing.

Scott, C., Black, J., \& Cranston, R. (2000), “Cranston's Consumers and the Law” Butterworths.

The Law Commission, (1987), "Sale and Supply of Goods" The Law Co, The Law Com No 160 and Scot Law Com No 104.

Twigg-Flesner, C. (2004), “Information Disclosure about the Quality of Goods¥ Duty or Encouragement?”. in R Howells, G., Janssen, A., and Schulze (ed), Information Rights and Obligations: A Challenge for Party Autonomy and Transactional Fairness, Ashgate Aldershot.

Twigg-Flesner, C., Canavan, R., \& MacQueen, H. (2016), “Atiyah and Adams' Sale of Goods”, Pearson Higher Ed.

— Schulze, R., \& Watson, J. (2018), "Protecting rational choice: information and the right of withdrawal.” In Handbook of Research on International Consumer Law, Second Edition. Edward Elgar Publishing.

Willett, C. (1993, “The quality of goods and the rights of consumers”, N. Ir. Legal Q., 44, 218.

_., Morgan-Taylor, M., \& Naidoo, A. (2004), “The sale and supply of goods to consumers regulations", Journal of Business Law, 94-94

Yidana, N. (2019), "Protecting Consumers in Ghana: A comparative Analysis of the Quality Requirements regarding the Supply of Goods to Consumers in Ghana and the UK as influenced by EU Law., PhD Thesis submitted to the University of Hull for the Doctor of Philosophy Degree in Law

Nuhu Yidana, PhD in Law (Hull), LLM (Leeds Beckett), PGD (Hull), CEMBA, BA Law \& Soc. (KNUST) Sessional Lecturer, Law School, University of Hull; Lecturer (on leave), Tamale Technical University, Tamale, Ghana. This article is a modified version of an aspect of quality of goods discussed as a part of the author's thesis submitted to the University of Hull, UK for the award of a Doctor of Philosophy Degree. The main thesis was funded by the Ghana Education Trust Fund (GETFund). The author would like to thank Professor Christian TwiggFlesner, Professor Mike Whitehouse, Dr. Mike Varney and Diana Wallis for their insightful comments and suggestions to earlier drafts of aspects which forms part of this article. The author remains responsible for errors and miscomprehensions. 